\title{
THE ORANGE ORDER IN SCOTLAND BETWEEN THE WARS
}

SUMMARY: This paper focuses on the theme of religious conflict within the working class in inter-war Scotland. It pays particular attention to the Protestant working class of the industrial lowlands and to the role of the exclusively Protestant secret society of Irish origin, the Orange Order. It attempts to explain why the inter-war period saw an upsurge in membership of sectarian organisations like the Orange Order and their activities; and at the same time was notable for a broadening of Labour Party support among the working class which transcended religious divisions. It argues that sectarian and class loyalties often went together and in some ways reinforced each other. The Orange Order leadership's Conservative politics is stressed but it is contended that the Order's appeal to the working class was to a large extent based on issues such as education and mixed marriages and perceived Irish Catholic immigration, issues which did not break down neatly into party political terms. It is argued that the Orange Order's social role was of great significance in this period of economic austerity and mass unemployment.

\section{Introduction}

The Orange Order came into existence in County Armagh in Ireland in 1795, the product of conflict between Protestants and Catholics over land and employment. It was, initially, a society controlled by the Church of Ireland landed gentry and a Loyalist force pledged to defend Crown and Constitution against rebellious elements in Ireland. It is believed to have played a prominent part in putting down the United Irishmen rebellion of 1798. ${ }^{1}$

During the nineteenth century the Order, while remaining an oathbound, masonic-style secret society and exclusively Protestant, became less identified with the Established Church and the landowners, and more of a pan-denominational body which included many Presbyterians, notwithstanding the participation of large numbers of the latter in the 1798 rebellion in Ulster. The Order also became decidedly more plebeian in terms of its social profile. In the nineteenth century the Order spread to Scotland and England and several points of the Empire; however, it was in Scotland, mainly through the efforts of the considerable numbers of Protestant Irish

${ }^{1}$ For the origin and early development of Orangeism see H. Senior, Orangeism in Ireland and Britain 1795-1836 (Londen, 1960). 
migrants, that its strength and influence were greatest. ${ }^{2}$

Even in the inter-war period of the twentieth century, the most salient characteristic of the Orange Order in Scotland was its importance as a focus for the Protestant Irish in Scotland. This article will suggest that a sense of Protestant Irish identity, built up during the nineteenth century by successive waves of immigrants, was maintained in the early decades of the twentieth by immigrants and their Scottish-born descendents; this was done principally through the Orange Order, but also through a collection of "satellite" organisations around it such as the Glasgow Ulster Association (a friendly society originally called the Glasgow Antrim and Down Benevolent Association when set up in 1883), the Orange and Protestant Friendly Association, the Royal Black Preceptory, the Apprentice Boys of Derry, and some Church congregations which were usually led by evangelical Irish Protestant preachers. These organisations were where a distinctively Irish Protestant presence was felt, a presence concentrated in the industrial west of Scotland - in Glasgow, Lanarkshire, Ayrshire and Renfrewshire, but also to a limited extent in Dunbartonshire, Stirlingshire and the Lothians.

Significantly, the main source of information about these organisations, particularly the Orange Order, is the files of the Belfast Weekly News which carried notes on their activities throughout the period under study; relatively little information can be gleaned from the Scottish press or, indeed, any other Scottish sources. The other main source referred to here is an English-based journal, The Orange Standard, which appeared between 1914 and 1928.

The Belfast Weekly News's reports on Orange lodges in Scotland varied in the amount of detail they carried but they are generally an invaluable guide to Orange activity of a religious, political and social nature. They help us considerably in determining which of these adjectives best describes the Orange Order in this period. Moreover, they provide insights into the role of women in the Order, into the appeal of the Order in a popular cultural sense, and into the dynamics of Protestant-Catholic relations in this very politically fluid, economically depressed and socially tense era.

Of course, the Orange Order in Scotland had to address issues of peculiar relevance to Scotland, and this article will consider these. However, its overall character, as in the nineteenth century, continued to be defined by Irish indices such as the names of lodges, the imagery of the Order's

${ }^{2}$ Elaine McFarland's Protestants First (Edinburgh, 1991) is a pathbreaking work on the Orange Order in nineteenth-century Scotland, and on Protestant Irish immigration. It is based on her doctoral thesis "The Loyal Orange Institution in Scotland 1799-1900" (University of Glasgow, 1986) which I have used as my main reference point for the nineteenth-century background. On the theme of Protestant Irish immigrants see also G. Walker, "The Protestant Irish in Scotland", in T.M. Devine (ed.), Irish Immigrants and Scottish Society in the Nineteenth and Twentieth Centuries (Edinburgh, 1991), pp. 44-66. 
banners and regalia, the overriding importance of Irish affairs in the Orange list of priorities, and the large number of Irish-born members, especially office-bearers, down into the 1930s. A couple of items from the Belfast Weekly News will illustrate the point. In December 1934 a report of an Orange social gathering in Grangemouth stated that the majority present was of the younger generation and "Sons of Scotland"; the report went on to say: "The Ulster element was also represented, but, unlike similar gatherings in Glasgow and the West, Ulster's sons were here in the decided minority."3 Back in January 1929 the Reverend James Brisby, an Ulsterborn maverick preacher who had, in tandem with the Orange Order, organised a formidable anti-Irish Home Rule campaign in Scotland before the First World War, addressed the "Loyal Sons of Ulster" lodge in Glasgow as follows: "As sons of Ulster they had the honour of Ulster to maintain in that city of Glasgow, and to give the people of Scotland to understand that they belonged to an unconquered and imperial province. That was the proudest heritage that anyone could claim, to be an Ulsterman and the son of an Ulsterman. Let them realise their responsibility of leading clean, straight, upright lives, maintaining their principles, and the people of Scotland would respect them.", It is most significant that a speech like this could have been made as late as 1929; it surely indicates that an Irish Protestant community identity was a fact of life for thousands of people in Scotland, although its profile was not as high as that of its Catholic Irish counterpart. It is impossible to say - without access to Orange Order membership records - just what percentages of the Order's membership were Irish and Scottish. The situation, of course, is confused by the large number of members who would have been Scottish-born with Irish parents or grandparents. If Orange Order membership claims of around 40,000 are taken as in any way accurate as an average over the inter-war period ${ }^{5}$ the majority would undoubtedly have been Scots born, but it is doubtful if more than a small minority would have had no Irish family background. The situation is further complicated by the likelihood of Irish settlers in Scotland being of Scottish descent themselves. What is more important to stress is the way that cultural bonds between Scotland and Ulster were constantly affirmed and celebrated in Orange rhetoric and oratory. It is also important to state right away the overwhelmingly proletarian character of the Order, as established in the nineteenth century. ${ }^{6}$ Irish Protestant immigration to

${ }^{3}$ Belfast Weekly News (hereafter BWN) 28 December 1934 (my emphasis); BWN references, unless otherwise stated, are to the "Scottish Orange Notes" column in the paper.

4 Ibid., 31 January 1929.

5 According to the Scottish Orangeman's Historical Directory 1913-1914 (British Library, pp. 2510 bac) the Order had almost 400 lodges at this time. Their numbers grew considerably after the First World War.

"See McFarland, "The Loyal Orange Institution", p. 96. 
Scotland was of an industrial worker variety, often skilled but just as often labourers. The Order sought to ingratiate itself with business and professional people, but any successes it contrived in this respect were largely overlooked by the Scottish establishment and Scottish press which took, in general, a disparaging view of its activities. Notwithstanding the force of anti-Catholic sentiment among Scots of all classes, there was much dislike of Irish political and religious quarrels being imported into Scotland. For all the Order's religious professions, the mainstream Scottish Churches regarded it balefully, although it should be said that there were individual Clergymen who gave it their blessing and who responded heartily to its warnings about Catholic Church activities in Scotland. However, the image held by some outsiders of the Orange Order having had great leverage and influence in the realms of employment, and political and religious affairs, has to be set against the self-perception, on the part of Orange leaders and rank and file, of the movement's marginalisation, of its struggle against the hostility of the bulk of Scottish opinion-formers. ${ }^{7}$ Certainly, the role of freemasonry with which, in terms of organisational structure the Orange Order had much in common, seems to have been of far greater moment in those areas of Scottish life where the Orange Order has been said to wield power and influence. $^{8}$

\section{Politics in the aftermath of the Great War}

Spokesmen for the Orange Order, and its own historians ${ }^{9}$, have always claimed that the organisation is first and foremost a religious body. Support for and loyalty to the British monarchy, constitution and laws, have always been conditional on their guaranteeing Protestant religious hegemony and keeping the Roman Catholic Church from the levers of State power. Declarations of The Order's religious credentials above all else were made by officials in Scotland in the inter-war period with some regularity. ${ }^{10}$ However, scrutiny of the reports of the speeches made by leadership figures at Orange meetings reveals much political content; indeed, political and religious concerns were repeatedly fused to produce an identification of

${ }^{7}$ See Grand Master McInnes Shaw's speech about Catholic influence on the press in Scotland, $B W N$, 5 February 1931.

${ }^{8}$ For the only penetrating analysis of Freemasonry in modern Scotland to date see G.P.T. Finn, "In the grip? A psychological and historical exploration of the social significance of freemasonry in Scotland", in G. Walker and T. Gallagher (eds), Sermons and Battle Hymns: Protestant Popular Culture in Modern Scotland (Edinburgh, 1990), pp. 160-192.

${ }^{9}$ See M.W. Dewar, J. Brown, and S.E. Long, Orangeism: A New Historical Appreciation (Belfast, 1967).

${ }^{10}$ See, for example, reports of speeches by Frank Dorrian, $B W N, 11$ January 1934, and McInnes Shaw, $B W N, 15$ December 1938. 
Catholicism with "disloyal" political activity in a campaign which was perceived as having the objective of undermining Protestantism in Scotland.

The Orange Order had had strong links with the Conservatives (or Unionists as they were more commonly known in Scotland after the Irish Home Rule issue) $)^{11}$ since the 1870 s. The links were formalised before the First World War when the then Grand Master the Reverend David Ness (who was to hold this supreme office until 1925) was co-opted to the Executive Committee of the Western Divisional Council of the Party. ${ }^{12}$ The Unionists' pro-Ulster stance in the Home Rule dramas of the 1880 s and 1912-1914, rallied the Protestant Irish elements in Scotland and galvanised the Orange Order as a grassroots campaign machine in many working-class constituencies, perhaps most notably Partick and Bridgeton in Glasgow. ${ }^{13}$ The Order provided a populist flavour to the Unionist political message: they beat the drum for "King and Country" and Empire unity. Indeed, the Order, in the pre-war period, largely undertook in the West of Scotland, the role played so successfully by the Primrose League in England. ${ }^{14}$ The Primrose League did have a Scottish presence ${ }^{15}$, but its role was limited and often tended to fade into the more robustly energetic Orange movement.

The immediate post-First World War period was one of great political and social turbulence. It saw much industrial unrest, popular disenchantment with the government over unfulfilled promises, the strains on the social fabric produced by demobilisation and unemployment, and the wider international context of upheaval, particularly in Russia. In this period the Orange Order's presentation of itself as a bastion of patriotism and conservatism propelled it into open confrontation with the increasingly powerful political challenge mounted by the Labour movement.

The Order suffered considerable losses among its members in the war. In the Pollokshaws lodge, for example, nineteen volunteers fell in action. ${ }^{16}$ In the Anderston district lodges twelve out of fifty-two volunteers were killed, the rest wounded. ${ }^{17}$ Funds were raised for soldiers returning and large reunion meetings held. The movement was forced to re-organise and recruit new blood and this it did with notable returns. In June 1920 the

11 This has always been a more popular tag in Scotland than the word "Tory" with its aristocratic and privileged connotations.

${ }^{12}$ McFarland, "The Loyal Orange Institution", pp. 429-431.

${ }^{13}$ For an account of Orange anti-Home Rule campaigning in Bridgeton at this time, see diaries of Alexander McCallum Scott (Liberal M.P. for the constituency) 1912-1913, Glasgow University Special Collection.

${ }_{14}$ See M. Pugh, The Tories and the People (Oxford, 1985).

${ }^{15}$ See I.G.C. Hutchinson, A Political History of Scotland 1832-1924 (Edinburgh, 1986), pp. 222-223.

${ }_{16} B W N, 29$ May 1919.

${ }^{17}$ Ibid., 22 May 1919. 
General Secretary, in his report to the annual Meeting of Grand Lodge, stated that the previous year's intake of new members - some 4,151 in all represented the greatest net increase in membership in the Order's history in Scotland. ${ }^{18}$ It should be noted, however, that the figure comprises men, women and juveniles. Attendances at the annual 12th of July Battle of the Boyne parades also soared: in 1919 an estimated 15,000 attended at Rutherglen, ${ }^{19}$ just outside Glasgow, while in 1920 between 25,000 and 30,000 were said to have converged on Govan, with a further 5,000 in Motherwell. ${ }^{20}$ From the mid-1920s estimated attendances of 40,000 and 50,000 seemed to be the norm at these annual demonstrations. The General Secretary's reports, as publicised in the Belfast Weekly News, indicate that it was not until the depths of economic recession in the early 1930s that membership figures were adversely affected in this period.

Perhaps emboldened by the new wave of recruits, the Order adopted a relatively high political profile after the war. Essentially, this revolved around two issues: (1) the rise in labour unrest; (2) the 1918 Education Act which had been passed under wartime legislation. The latter piece of legislation, passed by the Conservative-dominated coalition government, provided - under section 18 of the Act - for the maintenance by the State of denominational schools in Scotland which meant, in practice, Roman Catholic schools. There was an immediate outcry on the part of some sections of Protestant opinion about such an issue being decided without recourse to an election, and the Orange Order undoubtedly profited from the anger which erupted. It may indeed be speculated that this was the single most important factor in the Order's membership boom. Certainly, the Order was sufficiently confident of the benefit of the issue to put up eight candidates for the elections to the Glasgow Education Authority in April 1919. In the event, five were returned, and only a tactical error in putting up three candidates in the one ward (Hillhead and Partick), deprived the Order of greater success. ${ }^{21}$ Among those elected were Grand Master Ness and the redoubtable Rev. Brisby. Sir Charles Cleland, an Orangeman and a leading Conservative, became Chairman of the new Education Authority. Education was to remain a hot topic, much exploited by the Order, throughout the inter-war era and, indeed, far beyond.

However, it is the other political topic which has to receive more attention at this juncture. The increasing orientation of working people towards Labour politics - in effect towards the Independent Labour Party (ILP) at

${ }^{18}$ Ibid., 17 June 1920 . The figures broke down as: 1588 men, 806 women, 1757 juveniles.

19 Ibid., 17 July 1919.

20 Ibid., 15 July 1920.

${ }^{21}$ Ibid., 10 April 1919. One candidate was elected for St. Rollox and Maryhill; 2 for Govan, Tradeston and Pollok; 1 for Hillhead and Partick; 1 for Springburn and Camlachie. 
this time in Scotland - filled Orange leaders with anxiety, especially when viewed alongside the upsurge in trade-union strength and industrial militancy which had taken place during the war. In January 1919 engineers on Clydeside struck for a 40-hour week and the dispute escalated to the point at which the government ordered tanks to George Square in Glasgow to avert public disorder. The city was indeed in a ferment, if only briefly. Orange Order leaders denounced the troublemakers and the agitators, as they saw them, and the fact that the strike was unofficial allowed them to play the "constitutionalist" card. ${ }^{22}$ At a special meeting of Motherwell Orange and Purple District Lodge in February, the following resolution was passed unanimously: "that we protest against the action of the selfstyled leaders in causing such an upheaval among the working classes at the present time, meanwhile pledging ourselves to assist the Government in every constitutional way". ${ }^{23}$ In a speech at the Boyne celebrations in July, the Rev. Buyers Black, a prominent Orange figure at this time, deplored the activities of "certain trades unions", and called on Orangemen to work for class harmony. ${ }^{24}$ As in Belfast at the same time, Orange spokesmen scapegoated those Catholics who worked, for example, in the shipbuilding industry. In Scotland, their presence was said to be proof of the effects of continuing Irish Catholic immigration and the cause of unemployment for demobilised soldiers. "Bolshevism" in the trade unions was blamed for such a state of affairs being allowed to transpire..$^{25}$

This was a heady cocktail of simplistic scapegoating, scaremongering and loyalist tub-thumping. It is not difficult to appreciate how it might have appealed to ex-soldiers who had returned to find themselves out of work and thus apparently unrewarded for their sacrifices. Some anger over this was directed at the Government and may be said to have taken a politically radical turn, but in the context of religiously divided Clydeside it seems likely that it found expression mainly through the loyalist rhetoric of the Orange Order, and also ex-servicemen's organisations and the ultra-patriotic British Workers' League which was also active in Glasgow during and after the war. ${ }^{26}$

The Orange Order leaders spared no effort, and used precious little logic, in identifying "Bolshevism" and Catholicism as soul-mates. They were on

${ }^{22}$ It is far harder to find Orange denunciations of official trade-union activity, and there were Orange leaders who made clear that they were not anti-trade union as such. See report of speech by Frank Dorrian, BWN, 26 January 1933.

${ }^{23} B W N, 20$ February 1919.

${ }^{24}$ Ibid., 17 July 1919.

${ }^{25}$ See "Ulster Scot" column in BWN, 28 August 1919.

${ }^{26}$ See H. McShane (with Joan Smith), No Mean Fighter (London, 1978), p. 84; see also C. Wrigley, Lloyd George and the Challenge of Labour (London, 1990), p. 44 regarding a "revolutionary socialist" ex-servicemen's organisation in Glasgow, and chapters 2-4 in general for the mood of post-war unrest. 
stronger ground when accusing Labour of forging a political alliance with the Catholic Church; Labour was well aware of the necessity of Catholic working-class support and had given every sign of seeking to champion it by viewing favourably the 1918 Education Act. Orange leaders drew attention both to this and to Labour's stance on the Irish question (their advocacy of self-government for the whole island and rejection of Ulster's stand for Union) as they campaigned for local Unionist candidates in municipal contests at the end of $1920 .{ }^{27}$ In March 1921 the Rev. Victor Logan, an Ulster-born minister at John Street United Free Church in Glasgow and another prominent Orangeman of this time, told an Orange gathering at St. Rollox in Glasgow that the "two great enemies" they faced were the Catholic Church and "Socialist propagandists". ${ }^{28}$ By this time the Orange leaders were also participating in the activities of the Scottish Economic League, an employers' organisation set up to counter the influence as they saw it of socialist propaganda on working people. ${ }^{29}$ Speakers invited from Ulster to address Scottish Orange audiences urged the formation of Protestant trade unions, echoing the establishment in Ulster of a Labour Association which was connected to the Unionist Party there. ${ }^{30}$

The Order called openly for employers to employ Protestants instead of "disloyal" Catholics. One Orangeman who was also an employer, Edward Douglas, did just this. Douglas was a native of Ulster who came to Glasgow in 1877 as a young man and found work with the shipping firm of James Spencer and Company on the Clyde. He rose steadily to become a partner in the firm and was responsible for its management. Douglas was something of a figurehead in the Orange movement, particularly in Govan where he was Master of the numerically strongest male lodge in Scotland. ${ }^{31} \mathrm{He}$ also ran a children's mission in the area. He was a paternalistic figure who boasted of the loyalty of his workmen. ${ }^{32}$ Other Orange leaders remarked favourably on the all-Protestant nature of that workforce. In May 1926, the Motherwell Orangeman Ephraim Connor, in his regular column of "Scottish Notes" for the English Orange publication, The Orange Standard, said that Douglas was "one of the largest employers of labour at the Docks on the Clyde", and "a strong believer in Orangeism first and always for employment. Would that other employers may likewise attend first to

${ }^{27} B W N, 28$ October 1920.

${ }^{28}$ Ibid., 10 March 1921.

${ }^{29}$ See $B W N, 10$ February 1921; for an account of the development of the Economic League see A.J. McIvor, “'A crusade for Capitalism': The Economic League, 1919-39", Journal of Contemporary History, 23 (1988), pp. 631-655.

${ }^{30}$ See reports of speeches by William Coote, $B W N, 15$ July 1920 , and William Grant, $B W N, 14$ July 1921

${ }^{31}$ Lodge Number 127. It won the "blue riband" for this throughout the inter-war period and always claimed in excess of 400 members.

${ }^{32}$ See report of his Lodge's social gathering $B W N, 3$ February 1921. 
Protestants and loyal citizens before taking on and keeping disloyal elements in Papists, Socialists and Communists." 33

Thus it is clear that the Orange Order did exercise influence on employment through the policies of Orange employers like Douglas, and it advanced a strong paternalistic employer-worker ethic which might well have made an appeal to workers who feared job insecurity in economically precarious times. ${ }^{34}$ Moreover, where it was possible for working men to advance, perhaps to the rank of foreman, through Orange connections, many were undoubtedly happy to do so; a presentation to Douglas at an Orange Social in 1921 was made on behalf of fifty foremen in his employ. ${ }^{35}$ However, the second part of Connor's remarks suggests that, for the liking of Orangemen, such employers as Douglas were all too few. Indeed, as will be made clear, Orange leaders like Connor harboured acute fears that Orange working men were increasingly turning against employers and falling under the influence of Labour activists. He believed that employers were failing to counter this by their reluctance - as he saw it - to put a premium on loyalty and religious solidarity.

\section{"The Orange vote"}

The inter-war period was one of byzantine political flux in Britain, and perhaps especially in Scotland. This was a period when both class and sectarian politics enjoyed boom times, if not continuously in both cases. It was, generally, a period of rising class consciousness and Labour political advance in Scotland, but so was it also a time when religious sectarian organisations, both Protestant and Catholic, of which the Orange Order was the largest but only one of many, made political inroads and strongly competing claims on working-class loyalties. It was a period of strange alliances and occurrences, of personal political odysseys, of the emergence

${ }^{33}$ Orange Standard (British Library, pp. 265h, hereafter O.S.), May 1926. See also October 1926 - James Spencer, the head of the firm, was also an Orangeman.

${ }^{34}$ Scholarly work on paternalism in an urban industrial context, such as Patrick Joyce's Work, Society and Politics (Brighton, 1980) for Lancashire, is much needed for Glasgow and the West of Scotland. Examples like Douglas tend to support Harriet Bradley's argument that it has survived, in different and changing forms, in the twentieth century in certain industries. See Bradley, "Change and Continuity in History and Sociology: the case of Industrial Paternalism", in S. Kendrick, P. Straw and D. McCrone (eds), Interpreting the Past, Understanding the Present (London, 1990), pp. 177-195.

${ }^{35}$ BWN, 3 February 1921. Foremen were often in positions of significant power. In certain industries they decided who to hire and fire, and thus were, potentially, able to regulate employment in a sectarian fashion. 
of fascism (limited in Scotland) ${ }^{36}$ and the strategical twists and turns of Communism, of the re-emergence of Scottish Nationalism politically, and of the eruption of the "demonstration politics" of the unemployed and the hunger marchers. ${ }^{37}$

The Orange Order might be said to have delivered crucial working-class votes to the Unionists in several key Scottish constituencies in these years. ${ }^{38}$ Its importance in this respect has probably been underestimated, due perhaps to the fact that the Order officially withdrew its representatives from the Unionist Party councils in 1922, in protest at the Irish Treaty of December 1921, and set up its own political party, the Orange and Protestant Party (OPP). This action underlined the uneasy nature of the Orange-Unionist relationship: from its nineteenth century beginnings, it had always been marked by the Orange insistence that its support was dependent on the Party upholding Protestant and Loyalist principles. ${ }^{39}$ The Order viewed the Irish Treaty as a betrayal of such principles and set out to make the Party pay a political price. Orange leaders were to proclaim their intention of doing this over other issues during this period such as the Catholic Relief Act of 1926, the appointment of an envoy to the Vatican, and, of course, the 1918 Education Act. ${ }^{40}$ Some Orange leaders, most notably Ephraim Connor, lambasted Unionists for allegedly pandering, in careerist fashion, to the Catholic Church and Catholic voters, and casting aside their Protestantism. ${ }^{41}$

However, the OPP never turned out to be a viable political proposition; the obvious reluctance of many lodges to set up branches, as is clear from Connor's Orange Standard columns, indicated that there was much disagreement within the Order about organising politically in opposition to the Unionists. ${ }^{42}$ Indeed, the Grand Master of the Order in Scotland after 1925, Archibald McInnes Shaw, was a Unionist MP (he had been elected for Renfrewshire West in 1924) and he never seems to have considered breaking with the Party. Neither also did the other Orange Unionist MPs of the

${ }^{36}$ The Orange Order refused to accord recognition to the "Fascisti" organisation in Scotland in the $1920 \mathrm{~s}$ - see O.S., September 1925. However, some members were obviously attracted to it and Connor warned them about its Catholic leanings as he saw them. See O.S., June 1925.

${ }^{37}$ For a stimulating account of the wider political developments of the period in relation to the theme of religious tensions in Scotland, see T. Gallagher, Glasgow: The Uneasy Peace (Manchester, 1987), chs 3, 4 and 5. For the hunger marches specifically see I. MacDougall (ed.), Voices from the Hunger Marches (Edinburgh, 1990).

${ }^{38}$ See J. Mitchell, Conservatives and the Union (Edinburgh, 1990) p. 10.

${ }^{39}$ See McFarland, "The Loyal Orange Institution", p. 407 (statement of Grand Master William Young).

${ }^{40}$ Both the Catholic Relief Act and the appointment of the envoy were the work of Baldwin's Conservative Government; the 1918 Act was passed by the Lloyd George Coalition Government which was largely Conservative in makeup.

${ }^{41}$ See, for example, O.S., August 1923.

${ }^{42}$ See, for example, O.S., July 1923. 
time, namely Sir John Gilmour, General Hunter Weston, Lt. Col. T.E.R. Moore, John L. Baird and William Templeton, although the latter's populist approach did not endear him to the Party hierarchy. Connor was undoubtedly correct in stating, in May 1926, that "the Unionist Party officially discountenances the introduction of religious feeling into elections" ${ }^{43}$ it became increasingly clear that the Party was deeply uneasy about its Orange image while always grateful for the support the Order could deliver to it. It is perhaps significant that details of Orange meetings were seldom published outside Orange journals, except in Northern Ireland. Orange leaders like McInnes Shaw, it can be guessed, might have found their position rather awkward if their more uncompromising remarks to Orange audiences had received wide publicity in Scotland. ${ }^{44}$

Notwithstanding all these points about the tensions in the Orange OrderUnionist Party relationship, a study of election results in the Inter-war years, combined with evidence of lodge activity detailed through the columns of the Belfast Weekly News and the Orange Standard, suggests that the Orange vote was a meaningful political factor, if an elusive one to define with complete certainty. In Glasgow the Order was particularly strong in the shipyard worker areas of Govan and Partick and Anderston in the West of the city, in the railway worker areas of Maryhill, Springburn and St. Rollox to the North, and in areas of the east end such as Bridgeton, Camlachie and Shettleston. All these parliamentary constituencies were predominantly working class and the kind of seat Labour could hope to secure after it had emerged as a political force in the post-World War One years. Eight of these seats mentioned above were, in fact, captured by Labour in its sensational electoral breakthrough in Glasgow in the 1922 election, a result which threw Conservative Orange leaders into a panic.

The political fortunes of these constituencies thereafter in our period provide some food for thought. ${ }^{45}$ The seat of Kelvingrove, which included the Anderston area and was largely a community of dockers and shipyard workers, returned a Unionist throughout the period. This was Walter Elliot, long regarded as a "progressive" Tory who had a benign effect on the Party's social outlook in Scotland and on its need to make an appeal across the community and across religious barriers. Even Elliot, however, was to be found thanking Orange voters at an Orange function in his constituency in 1931, a telling indication of their importance to him. ${ }^{46}$ In

${ }^{43}$ Ibid., May 1926.

44 This was suggested by Alexander Ratcliffe, leader of the Scottish Protestant League, who was a prominent critic of the Orange Order leadership in the 1930s. See below, p. 191. See his remarks in the SPL newspaper Vanguard (Mitchell Library Glasgow), 21 March 1934.

45 Election results and statistics contained in F.W.S. Craig, British Parliamentary Election Results, 1918-1949 (London, 1977).

${ }^{46} B W N, 19$ November 1931. 
1930 a leading Orangeman in the constituency, Jonathan Harvey, won a municipal election contest in Anderston and deposed the sitting Labour councillor. Harvey was the local undertaker and a native of Armagh in Ulster. ${ }^{47}$ In the same round of electons in the rest of Glasgow six Orange Order members (out of six) were returned. ${ }^{48}$

The Orange vote might also have been crucial in Maryhill where the Unionists triumphed in the 1924 election, and recaptured the seat from Labour in the albeit exceptional circumstances of 1931. The Unionist candidate for Maryhill in these contests, Douglas Jamieson, assiduously cultivated Orange support in the area by addressing several Orange social gatherings. In adjacent Springburn, the Unionists won this solidly workingclass seat in 1931, and McInnes Shaw chose it to make a stand (which proved unsuccessful) in a bye-election in 1937. Neighbouring St. Rollox was always Labour in this period but the Unionist vote was not unsubstantial and again an Orange popular base is discernible.

In the east Camlachie was always a hard-fought contest in these years, with the Unionists triumphing in 1931. Both here and in neighbouring Shettleston where William Templeton won a bye-election in 1930 , the Orange vote was, if the reports of its activities are any guide, well-disciplined and active. However, in Bridgeton, where the Order had a very high profile and where Unionist-sponsored organisations such as the Junior Imperialist League had been so active in pre-war days, ${ }^{49}$ the position of the charismatic Labour leader Jimmy Maxton remained impregnable.

In the West the Orange vote was clearly a decisive factor in Partick which returned Unionists in 1923, 1931 and 1935; Labour's history of municipal difficulties here reinforces the point ${ }^{50}$ By contrast, Govan, which boasted some of the strongest Orange lodges in the country, remained in Labour hands throughout the period, notwithstanding a strong Unionist challenge in 1931.

In addition to these Glasgow case studies, it should be noted that the seat of Rutherglen was won by the Unionists in 1931 and 1935; Lanarkshire North was won by Hugh Ferguson, an outspoken Orangeman, in 1923, and by the Unionists again in 1931; Lanark was won by Unionists in 1924, 1931 and 1935; Coatbridge was won by Templeton in 1931; and both Renfrewshire East and West were kept Unionist for the most part throughout the period. In all of these constituencies too, the Orange Order presence was

${ }^{47}$ Ibid., 13 November 1930.

48 Loc. cit.

${ }^{49}$ McCallum Scott Diaries, op. cit.

${ }^{50}$ See report of local elections in the ILP newspaper Forward, 13 November 1920. The correspondent called Partick a stronghold of "Carsonism", although some of this feeling may have died down as the inter-war period wore on, and passions over the Irish issue relaxed. 
notable and evidently of more than a little political use to the Unionists, although this is clearer to discern in cases like the industrial town of Motherwell than for example, the large Renfrewshire seats with their greater mixture of social classes.

\section{Religious and class loyalties}

There is another way of looking at this electoral picture. It would be equally valid to stress Labour's successes in the constituencies mentioned, and to argue that the Orange Order's political role on behalf of the Unionists had very real limitations. ${ }^{51}$ This is the obvious conclusion to draw from the statistics concerning such constituencies as Govan and Bridgeton. And in acknowledging such limitations, we are led on to consider more carefully the question of the political behaviour and loyalties of the rank and file - as opposed to the leadership - of the Order. This, it might be suggested, is a highly complex question.

The first point to stress - or rather to consider in a different light - is the Orange leadership's concern to attack Labour and Socialism so relentlessly and, it might be said, so desperately. No one did this more than Ephraim Connor, the Scottish correspondent of the Orange Standard, for whom combating socialist influences became a personal obsession. Connor wrote a series of articles in the Standard on the theme of whether an Orangeman could be a socialist, a question he answered emphatically in the negative. However, in the course of his arguments he seemed to be acknowledging that many Orangemen were attracted to socialism. ${ }^{52}$ For Connor this may simply have meant trade-union membership for this too alarmed him: "You Orangemen and women [ . . ] how can you support in any manner by voting for, working or, aye, by being members of a Trade Union affiliated to and assisting by your political levy such an ungodly, blasphemous, unpatriotic body of men known as the Labour Party [. . . ] come out of her my people, be not partakers of her sins, lest ye partake of her plagues!"53

It is clear from this that Orange Order officials looked suspiciously on any kind of working-class organisation or activity over which they had no control, and which involved Protestant and Catholic cooperation. The question of the trade-union levy being paid to the Labour Party obviously rankled but taking on trade unions, or attempting to stop members joining

51 A study of municipal contests in Glasgow yields similarly ambiguous evidence. In 1938, for example, the Orange vote in wards like Dennistoun, Pollokshaws, Whiteinch and Sandyford might have helped the Tories (Progressives); however, Labour won wards such as Govan, Kinning Park, Govanhill and Whitevale where this vote could also be identified as significant. See Glasgow Herald, 2 November 1938 for detailed results. ${ }^{52}$ See $O . S$., June 1923.

${ }^{53}$ Ibid., October 1923. 
them, was a task beyond the Orange leaders. They attempted instead to prevent Orange Order members joining Labour and Communist political parties. In December 1923 at a Grand Lodge meeting in Glasgow in the wake of the election which produced a minority Labour government, it was agreed "that any member, male or female of the Orange Institution who joins the ILP, Communist or other socialist political party or who allies themselves politically with those bodies is to be expelled from the Order. Disloyalty cannot be tolerated within our Order." 54 Soon after, Connor called on Orangemen to "defy openly all the power - parliamentary or armed - of the Bolshevic Premier McDonald, and his Atheistic-Papish, anti-British mercenaries". Connor asserted that the advent of the Labour Government threatened the activities of the Order and rejoiced that "All socialists within the ranks have received their marching orders." 55

The hysterical nature of the response betrayed the alarm felt by Orange leaders about the spread of socialism and the appeal of Labour. It is clear that the leadership perceived a real problem in relation to this within the ranks of the order. The expulsion resolution was the ultimate weapon to use but even so there is evidence to suggest that it was not entirely effective. In November 1926 Connor's column carried a report of a motion tabled (but not accepted) at a Ladies Orange Association meeting referring to "the husbands of lady members being disloyal by their being members of Socialist and Communist organisations" ${ }^{56}$ Recently published oral testimonies of those involved in the Scottish hunger marches and unemployed demonstrations in the late 1920 s and early 1930 s state that Orange flute band members participated in the marches, that Orangemen joined the Communist-led National Unemployed Workers' Movement (NUWM), and that social and economic distress cut across religious loyalties however firmly held the latter were. ${ }^{57}$ In March 1932, in the wake of unemployed disturbances in which he seems to have known of Orange involvement, McInnes Shaw addressed an Orange gathering and said that the scenes were "not helping them and [were] not doing the Protestant faith any good". 58 The early 1930 s, in fact, saw a fall in Orange Order membership, and references on the part of officials to the adverse economic situation's effect on the Order could be interpreted as a clear decline in morale. There is even a suggestion of Order officials playing down the political aspect to their cause in this

54 Ibid., January 1924.

${ }_{55}$ Ibid., February 1924.

${ }^{56}$ Ibid., November 1926.

${ }^{57}$ MacDougall, (ed.). Voices from the Hunger Marches. See testimonies of Phil Gillan and Michael Clark.

${ }_{58} B W N, 3$ March 1932. 
period for fear of alienating the unemployed and impoverished in their ranks. ${ }^{59}$

The Orange Order might also have been galvanised into frenzied antiLabour activity in the early twenties as a reaction to the deliberate attempts made by labour activists and propagandists to win the allegiance of Orangemen. Indeed, it could be argued that the post-war years witnessed a noholds barred propaganda war between the Order and the labour movement for the loyalties of Protestant workers. The ILP newspaper, Forward, edited by Tom Johnston, one of the Labour MPs returned to Westminster in 1922, carried several articles in the early 1920s urging Orangemen to turn to the Labour cause and claiming that "thousands" of them had done so by joining the ILP or the Labour Party. ${ }^{60}$ During the war the nerve centres of the rent strikes on Clydeside were Govan and Partick and the strikes involved many men and women who were either Orange Order members or sympathisers. ${ }^{61}$ The ILP's leading role in these struggles seems to have won them the political loyalty of such people. Scrutiny of Forward reveals that certain ILP branches in Ayrshire used local Orange halls for meetings, ${ }^{62}$ and in areas of Ayrshire, Lanarkshire and the Lothians where both the Labour and Orange movements were strong there seems to have been some kind of rapport between them. In the 1930s a militant Protestant organisation, the Scottish Protestant League, led by Alexander Ratcliffe, made political waves at local level in Glasgow - it won several council seats in the early 1930s - and attacked the Unionists for their "softness" on Protestant issues. ${ }^{63}$ It might also be said to have reinforced or encouraged the suspicions of working-class Orangemen that the Order leadership was antagonistic to their material welfare and interests. Certainly, Ratcliffe did not take the view that Orangemen should not, in any circumstances, vote Labour, although he was loudly critical of Labour's cultivation of Catholic support. ${ }^{64}$

It can also be argued that the Orange Order was battling against the tide concerning the issue of industrial relations. Developments during the war and after in the heavy industry sector of the economy rendered the chances of paternalistic employer-worker relations less likely. The war, of course, gave rise to the celebrated workplace struggles against dilution in the munitions industry which triggered waves of industrial unrest involving

${ }^{59}$ See, for example, the address by Hunter Munn reported in BWN, 14 January 1932.

60 See Forward, 3 February 1923.

${ }^{61}$ See J. Melling, Rent Strike! (Edinburgh, 1983), pp. 70-71.

${ }^{62}$ See Forward, 23 March 1929.

${ }^{63}$ For Ratcliffe and the SPL see Gallagher Glasgow: The Uneasy Peace, pp. 150-158; S.

Bruce, No Pope of Rome (Edinburgh, 1985), ch. 2.

${ }^{64}$ See Vanguard, 20 September 1933. 
skilled workers in shipbuilding and engineering. Many of these workers and their unions, most notably the boilermakers, had strong Orange and Masonic allegiances. ${ }^{65}$ However, Orange loyalties usually did not prevent these workers acting collectively and combatively against employers on matters concerning pay and conditions, and they certainly did not prevent the expansion of trades unionism. Arguably, too, out of these struggles emerged a stronger sense of class consciousness, however undiminished sectarian loyalties might be. It is likely that Orangemen took part in the 40-Hour Strike in January 1919, and that knowledge of this further increased the Order officials' determination to curb labour militancy. ${ }^{66}$

This they proved unable to do. Industrial relations disputes over workplace practices, workplace bargaining, and control of the day-to-day workshop processes proliferated, and defeats at the hands of employers over such issues in the early 1920 s generated much bitterness and resentment among workers. ${ }^{67}$ Relations between employers and workers on Clydeside became increasingly adversarial. Many skilled workers began to abandon their sectional craft loyalties and embrace a wider sense of working-class unity. Slumps in the heavy industries resulting in lay-offs exacerbated the situation. In 1923 the Boilermakers were involved in a long drawn-out dispute with the Shipbuilding Employers Federation (SEF) in an attempt to resist changes in workplace practices which they believed would undermine their control. ${ }^{68}$ The introduction of welding in the industry in the $1930 \mathrm{~s}$ produced another such confrontation between the same parties. ${ }^{69}$ In engineering similar disputes took place over the restructuring of the labour process. ${ }^{70}$

Such important workplace developments perhaps ensured, more than any other single factor, that Protestant sectarian loyalties did not translate in a significant number of cases, into Conservative political loyalties. Many Protestant workers who were Orangemen or sympathetic to the Order in a tribal or communal sense could also be tireless fighters for their interests in

${ }^{65}$ See J. Foster, "A Century of Scottish Labour", Labour History Review, 55 (Spring 1990), pp. 64-68.

${ }^{66}$ On this point see also unpublished and unpaginated dissertation held in Mitchell Library Glasgow: W. Marshall, "The Development of the Orange Order in Scotland".

${ }^{67}$ See J. Melling, "Whatever Happened to Red Clydeside?", International Review of Social History, XXXV (1990), pp. 3-32 on skilled labour and workplace struggles; also K. Burgess, "Clydeside and the Division of Labour c. 1860-1930", Social History, 11 (May 1986), no. 2, pp. 211-233 regarding the issue of the control of supervisors.

${ }^{68}$ See J. McGoldrick, "Crisis and the Division of Labour: Clydeside Shipbuilding in the Inter-War Period", in T. Dickson (ed.), Capital and Class in Scotland (Edinburgh, 1982), pp. 143-185.

${ }^{69}$ Ibid.

${ }^{70}$ See A. McKinlay, "Depression and Rank and File Activity: The Amalgamated Engineering Union, 1919-1939", The Journal of the Scottish Labour History Society, 22 (1987), pp. 22-29. 
the workplace against employers. Such workers would thus most likely have considered it to be in their interests that their trades unions were strong and perhaps even militant, and also that Labour was a powerful political "pressure point" to fortify further the workers' position. As David Marquand has pointed out in relation to Labour voters in Britain more generally in this period, a vote for Labour was often cast in the spirit of an act of self-defence, and we should not forget the extent to which workingclass Labour and Tory supporters shared essentially the same values. ${ }^{71}$

Support for Labour need not have prevented Orange-minded workers expressing ultra-Protestant sentiments, marching on the Twelfth of July, and continuing to eye Catholics unfavourably. It should be remembered that very few Catholics featured in skilled occupational groups in the shipyards like the boilermakers. Thus a sense of workers' solidarity over industrial questions could also, in a way, reinforce Protestant solidarity they were all Protestant workers together fighting the bosses during the week and the Catholics at weekends! In mining areas where the Orange Order was strong, and grew stronger, in the inter-war period, a similar situation seems to have obtained: pit towns and villages in Ayrshire, Lanarkshire, Dunbartonshire, Stirlingshire and the Lothians were often distinguished by their combination of Labour militancy and religious tribal feeling, Catholic as well as Protestant. ${ }^{72}$ Certainly, it seems to have been the case that workers did keep different sets of loyalties apart to a great extent and that if they recognised contradictions in them, then this was something they were prepared to live with. There were thus important limitations to both class and sectarian loyalties and behaviour.

Notwithstanding their pro-employer rhetoric, it seems also to be the case that Orange leaders could exercise only very limited influence on employers. A few Orange leaders were employers themselves; the examples of Douglas and Spencer have been cited, and the Deputy Grand Master in the 1920 s, Frank Dorrian, was a coal contractor.$^{73}$ However, these were the exceptions rather than the rule and there is no evidence that the Order was plugged into the higher economic and financial echelons of society. On the contrary, the plaintive tone and content of the leaders' speeches during the period rather suggests that they were frustrated that they could not exert more effective influence. Much bilious speech was directed at employers, and in particular local authorities, for allegedly employing Catholics ahead of Protestants. ${ }^{74}$

${ }^{71}$ D. Marquand, The Progressive Dilemma (London, 1991), ch. 5.

7 Protestant examples might be said to be Broxburn and Bo'ness in West Lothian; a Catholic example is that of Croy in Stirlingshire.

${ }^{73}$ See T. Gallagher, Glasgow: The Uneasy Peace, p. 144.

${ }^{74}$ See, for example, the speech by Digby S. Brown, as reported in $B W N, 30$ January 1930. 
In the trough of the economic depression, in 1932, the Order set up Committees to give advice to unemployed members on the matter of unemployment benefits. ${ }^{75}$ This was a deliberate attempt to counter tradeunion and labour activities in this area, and the signs suggest that it failed quite ignominiously. ${ }^{76}$ All in all, the Orange Order found it increasingly difficult, and indeed hopeless, to attempt to steer their members away from trades unions and, in some cases, from Labour and even Communist politics. Their political message - where it demanded worker loyalty to the firm rather than the Union - was often simply ignored, and its success in winning the Orange working-class vote for the Unionists was also strictly limited. Labour's political successes in Glasgow and the industrial belt in Scotland - in 1922 and after - required a large Protestant working-class vote as well as the Catholic vote; some of this vote, it can be suggested, was also Orange-coloured. ${ }^{77}$

In addition, the removal of the Irish question from British politics in 1922 undoubtedly diminished the potential for sectarian political conflict, and it also opened the way for the Labour Party to appear more constitutionalist and "safe" in the eyes of Orangemen who had been offended by its stance on the Irish issue and the enthusiastic support of some of the party's spokesmen for the aims of Sinn Fein. The experience of Ramsay McDonald's one year minority government from 1923-1924 might also have calmed the nerves of those who had been receptive to the dire warnings of Orange leaders like Connor.

\section{"Peaceful penetration"}

The issue of unemployment, as has been argued, was a difficult one for the Orange Order. It led to lapses in membership and apparent participation, in some cases, in left-wing demonstrations on the problem. However, it was also an issue which could be hitched to what, in the circumstances of these economically-depressed years, was a very potent Orange rallying cry: that of opposition to perceived waves of Irish Catholic immigrants to Scotland. Statistical evidence on this question, when supplied for instance by the Glasgow Herald in $1929,{ }^{78}$ showed that the actual numbers of Irish im-

${ }^{75} B W N, 16$ June 1932, General Secretary's Report.

${ }^{76}$ See $B W N, 15$ June 1935 . The General Secretary's report was still very gloomy on economic matters and no progress in relation to the welfare initiative was reported.

${ }^{77}$ This is also argued in an unpublished paper by J. Melling and I. Patterson, "Sectarianism and Socialism: William Reid and the politics of Labour in Glasgow, 1912-1965". My thanks to the authors for permission to cite their work. See also I. Patterson, "The Impact of the Irish Revolution on the Irish Community in Scotland 1916-23" (M. Litt, University of Strathclyde, 1991), pp. 284-289, 293, regarding Labour successes in areas such as Larkhall.

${ }^{78}$ Glasgow Herald, 25 March 1929. See Gallagher, Glasgow, p. 167. 
migrants had slowed to a trickle. Between 1876 and 1921 some 94,000 Irish emigrants, both Catholic and Protestant, established themselves in Scotland, but this was far less than the number who came in the 1840s and 1850s. The trend continued downwards in the inter-war period, although it has been suggested that the proportion of immigrants coming from the heavily Catholic Ulster counties of Cavan, Monaghan and Donegal rose. ${ }^{79}$ However, statistical niceties counted for little against what people perceived to be the reality of the situation. For Orange Order members, that reality was one of "Peaceful Penetration", a phrase used repeatedly in Orange speeches and, indeed, by some in other more "respectable" walks of Scottish life. . $^{80}$ The latter included Church ministers who had no Orange connections - the Church of Scotland, indeed, discussed the subject at its General Assembly in 1923 after an alarmist minority report had been submitted to it. ${ }^{81}$ It was also a topic which exercised some literary and professional people, such as the novelist and Scottish Nationalist, George Malcolm Thomson, whose fiction stressed the point about people believing what they saw in practice rather than what they were told in the abstract. ${ }^{82}$

What many people believed they saw was a gradual takeover by Catholics of Irish background of areas of life that Protestant Scots, and presumably Protestant Ulster-Scots, considered as testimonials to their qualities of industry and inventiveness. It is no accident that Orange rhetoric made much of alleged Catholic Irish infiltration of the shipyards. There was a powerful symbolism here; the issue was presented as outsiders, and indeed "traitors", taking over jobs in the "engine room" of Scottish (and British) economic prosperity and greatness: a strike at the heart of the Empire in effect. Orangemen believed that the whole process really started in the war when - again symbolically - so many shipyard workers left their jobs to serve their country and thus left their industry "exposed" to penetration, penetration aided and abetted by "Bolshevic" agitators who were in league with Sinn Fein. The following poem was sent by a Partick Orangeman to the Orange Standard in 1922; it is entitled "The Pope's Letter to Joe Devlin", Devlin being the Irish Nationalist politician and leader of the Catholic sectarian society, the Ancient Order of Hibernians (AOH). The Partick Orangeman wrote:

While our boys knew where best to go - the safest place to hide

Was to get a job at labouring in a boatyard on the Clyde

They took the place of other men who went to do the 'straffer'

${ }^{99}$ B. Collins, "The Origins of Irish Immigration to Scotland in the Nineteenth and Twentieth Centuries", in T.M. Devine (ed.), Irish Immigrants and Scottish Society, pp. $1-18$.

8" See examples noted by Gallagher in his Glasgow: The Uneasy Peace, p. 138.

${ }^{81}$ See Callum Brown, The Social History of Religion in Scotland since 1730 (London, 1987), pp. 237-238. See also Bruce, No Pope of Rome, pp. 46-47.

${ }^{82}$ Thomson is discussed in Gallagher, Glasgow: The Uneasy Peace, p. 169. 
And got safe jobs for all their pals by boozing up the gaffer

They played their part right well, we know, a lot of well-trained schemers

Who went about like little lambs while they were hot Sinn Feiners. ${ }^{83}$

In such an economically troubled time as the inter-war era it was perhaps unsurprising that Protestants (and Catholics) without work, would be receptive to claims that "the other side" was looking after its own while those who deserved work for, in the Protestant case, their supposed loyalism or "soundness" politically, went scandalously unrewarded. As the recession bit harder the beliefs entertained about conspiracies and plots grew wilder. Typical sentiments were expressed by the Rev. R.F. Whiteley when he counselled an Orange gathering in 1931 as follows: "They lived in difficult times, difficult because of the lack of employment, and he would speak a word to any who had influence in that connection that they would not forget their brethren of the Orange Order, because they knew only too well that those of the other side had their passwords and such like which they could well use, so that it was necessary for Protestants and Orangemen to defend themselves and to see that they got a fair chance in any work that was available." 84

The more astute Orange orators could, in relation to the issue of unemployment, make much of the perceived unfairness of the 1918 Education Act. Not only did Section 18 of this Act guarantee the right of Catholics to their own schools at the State's expense, but it also gave the Church a veto which could be exercised over appointments to Catholic schools. As Steve Bruce, in his study of militant Protestantism in Scotland, has pointed out ${ }^{85}$ the issue had powerful propaganda potential for extreme Protestants - it could be presented as meaning that in practice Catholics could get jobs in state schools on merit while Protestants would be denied posts in Catholic schools on account of their religion. The issue, indeed, remains a topical and controversial one even today. ${ }^{86}$

However, it was not so much the Orange order as the extreme Protestant organisations which emerged in the 1930s - the Scottish Protestant League and Protestant Action - which mined this issue most energetically. The SPL was led by Alexander Ratcliffe and was based in Glasgow; PA was led by John Cormack and was active mainly in Edinburgh. ${ }^{87}$ Both Ratcliffe and Cormack were egotistical, rabble-rousing figures (who could not stand each other) in an age marked by such politics of demagoguery. Ratcliffe was the

${ }^{84} B W N, 26$ March 1931.

${ }^{85}$ Bruce, No Pope of Rome, pp. 43-46.

${ }^{86}$ See, for example, Glasgow Herald, 1 November 1990.

${ }^{87}$ For Cormack and P.A. see T. Gallagher, Edinburgh Divided (Edinburg, 1987), passim, and Bruce, No Pope of Rome, ch. 3. 
more plausible operator, his written propaganda skills being in a different league from Cormack, and he used issues concerning the Education Act along with other arguments in effect to steal the thunder of the Orange Order (which he lambasted as ineffectual and compromising) ${ }^{88}$ and to stir up still further the fears and suspicions of many ordinary Protestants about Catholic activity.

For Ratcliffe it was not just jobs Catholics were taking from Protestants; they were also taking over buildings for their own schools and chapels. In 1933 the SPL's success in the Glasgow Corporation elections - it won 23\% of the total vote ${ }^{89}$ - can in part be attributed to local resentment in places like Cathcart about school buildings being taken over by the Catholic Church. ${ }^{90}$ Ratcliffe's message that Catholics voted as Catholics in politics, particularly at municipal level, that they voted at the behest of their priests, and that they voted for candidates who satisfied them about their support for Catholic interests - all of this struck a powerful chord with Protestants who seemed to discern a corresponding lack of leadership on the part of their own Churches, or who felt anxious about their own cultural identity or economic or social position. ${ }^{91}$

What is clear is that Glasgow and the West of Scotland - and Edinburgh too, thanks to the efforts of Cormack - had a lot in common with the sectarian tensions of Belfast and Northern Ireland in the same period. As in Northern Ireland, tensions were fuelled by rumour - rumours that jobs and housing and favours were going to the "other side", that one's own side was being betrayed or let down by weak-kneed leaders; in short, the sectarian "zero sum" game. ${ }^{92}$ Such tensions resulted in bloody riots in Belfast in 1935, riots in which Glasgow Orangemen, over for the 12th of July celebrations, played a lively role. ${ }^{93}$ Street riots also broke out in Edinburgh in the same year, and wild scenes accompanied the Orange celebrations in Glasgow which took place a week before those in Belfast. Glasgow's religion-based football rivalry between Rangers and Celtic intensified between the wars. ${ }^{94}$ In Scotland, as in Northern Ireland, enough Protestants took seriously the

${ }^{88}$ Ratcliffe was a member of the Orange Order until sometime around 1930.

${ }^{89}$ Gallagher, Glasgow: the Uneasy Peace, p. 153.

${ }^{9}$ See Vanguard, 27 September 1933 and 8 November 1933. There was also friction between Protestants and Catholics on Lanarkshire Education Board over Catholic school building in 1924. See Connor's notes in O.S., February 1924.

${ }^{91}$ See Bruce, No Pope of Rome, p. 75 for discussion of the kind of people Ratcliffe appealed to.

${ }_{92}$ For a Scottish example of such claims see $B W N, 18$ September 1930 regarding the employer who claimed to have discovered his Catholic foreman hiring other Catholics on instructions from his priest.

${ }^{93}$ See A.C. Hepburn, "The Belfast Riots of 1935", Social History, 15 (January 1990), pp. 75-96.

${ }^{94}$ See Bill Murray, The Old Firm (Edinburgh, 1984), chs 5-7. 
concept of "Peaceful Penetration" of important areas of public and social life by Catholics, to believe that their own position was at risk and that militancy and aggression were called for to turn back the tide.

In 1932 McInnes Shaw raised the spectre of a "Roman Catholic State" in Scotland and used the fighting talk he evidently felt his followers wanted to hear and that if he did not satisfy them with someone like Ratcliffe would: "Almost every week in their city they saw houses being taken over by the Church of Rome. In a certain district there seemed to be an attempt to set up a citadel of the Roman Catholic Church, and Protestants allowed them to go on doing these things." 95 Orange leaders like Shaw frequently lamented the lack of Protestant unity in comparison with Catholicism; they believed that their opponents were united and energetic in pursuit of their ends while Protestants were insufficiently vigilant and lacking the same unity of purpose. ${ }^{96}$ Frank Dorrian was clearly troubled by such thoughts when he issued the following warning to his audience after the outbreak of the Second World War, a message which encapsulated the Orange view of the effects of the First: "Let them also see to it that when their kith and kin were away defending The Empire their jobs were not filled by those who had ever been rebels to Britain and the British constitution." 97

\section{Catholic activity}

The belief in the idea of "peaceful penetration" may have been simplistic but it was of a piece with the edgy climate of the times in general, and it also has to be seen in the context of what was a very real amount of Catholic activity in Scotland in these years.

The profusion of Protestant organisations in Scotland in this period has already been noted. Besides the Orange Order, the SPL, and P.A., there were small local organisations such as the Shettleston Protestant Club, the Protestant Defence Association in Bridgeton, the Protestant Vigilance Society run by the Reverend Frederick Watson in Motherwell, and the Protestant Progressive Society in Broxburn, West Lothian. This by no means exhausts the list - there were also popular Protestant Church-linked youth organisatons such as the Boys Brigade which was predominantly working class - and, of course, there are also good arguments for viewing the Freemasons as an essentially Protestant organisation in Scotland. ${ }^{98}$

However, these organisations had their Catholic counterparts. The $\mathrm{AOH}$ has been mentioned; it was the closest Catholic equivalent of the

${ }^{95} B W N, 10$ November 1932.

* See, for example, the report of his speech in $B W N, 12$ July 1934.

${ }^{97}$ Ibid., 19 October 1939.

${ }^{98}$ See Finn, "In the grip? Freemasonry in Scotland", passim. 
Orange Order and was blatantly sectarian. The esoteric Catholic secret society, the Knights of St. Columba, was formed in Glasgow in 1919. The Catholic Union, as Tom Gallagher has shown, ${ }^{99}$ was particularly energetic in the inter-war period in the realm of politics; it saw its task as organising the Catholic vote and ensuring that Catholic interests in matters like education were looked after in the political arena, which meant, in the Scottish context, that they would be looked after by the Labour Party. However, just as the Orange Order could regard the Unionists as inadequate on matters of Protestant interest, so the Catholic Union clashed with Labour on issues such as divorce, birth control, and the Spanish Civil War of 1936-1939. It should also be noted that the Labour Party had dealings with the AOH from time to time; in 1921, for example, six AOH members stood for Labour in municipal contests. ${ }^{100}$ It was clear that Catholic organisations did exercise an important influence over the choice of Labour candidates in some constituencies. ${ }^{101}$ The idea of a separate Catholic political party was mooted in the early $1930 \mathrm{~s},{ }^{102}$ and the Catholic Union has been viewed as one in "embryo". ${ }^{103}$ Vocational guilds were formed among Catholic workers which functioned as quasi-trade unions. ${ }^{104}$ Catholic Action, an active propagandising body, was busy in certain industries in attempting to combat what it viewed as iniquitous Communist activity ${ }^{105}$ - something Orangemen chose to ignore in their propaganda.

There was also something of an upsurge in the public display of popular Catholic devotion in this period. Organisations like the Legion of Mary and the Catholic Young Men's Society organised such displays, the most controversial of which was the erection at Carfin (in Lanarkshire) of a grotto for which miraculous properties were claimed. ${ }^{106}$ The Orange Order saw this as a challenge thrown down at them, and they consequently arranged for parades and demonstrations in the area which occasioned outbreaks of trouble. ${ }^{107}$ As in the case of the perceived Catholic "infiltration" of the shipyards, the Carfin grotto was viewed as a deliberate case of Catholic aggression in the symbolical territory of Scotland's industrial heartland. In addition to this, a triumphalist tone was sometimes discernible in Catholic

\footnotetext{
${ }^{99}$ See Gallagher, Glasgow: The Uneasy Peace, pp. 118-120, 202-203.

${ }^{100}$ See W. Knox, "Religion and the Scottish Labour Movement", Journal of Contemporary History, 23 (1988), pp. 609-630.

101 Ibid. Knox makes clear that some Labour members were unhappy about Catholic influence.

102 Reported in Irish News, 5 May 1933.

${ }^{103}$ Gallagher, Glasgow: The Uneasy Peace, p. 106.

104 Ibid., p. 124.

105 Ibid.

${ }^{106}$ Gallagher, Glasgow: The Uneasy Peace, p. 106.

107 See report of Grand Lodge half-yearly meeting in $B W N, 18$ June 1931, and also $B W N, 1$ September 1932 and 18 May 1933.
} 
public statements, particularly in relation to converts from Protestantism, and an Orange backlash was assured. ${ }^{108}$

However, the issue which probably did most, aside from education, to mobilise outraged Protestant opinion, was the Catholic Church's stance on mixed marriages. On this issue, the Church attempted to enforce the Papal Decree "Ne Temere" (1908) which held that the marriage was invalid unless sanctified by the rites of the Catholic Church. The Church also insisted that children of mixed marriages be raised in the Catholic faith. Catholic intransigence on the matter of how children were brought up was illustrated by the Catholic Union's attempts to take orphaned Catholic children out of Protestant homes. ${ }^{109}$ The Catholic position on mixed marriages, in fact, was seen as a direct challenge to the law of the land by the Orange Order and other militant - and not so militant - Protestants. In 1933 the Order drafted a Married Persons Protection Bill to counter "Ne Temere" which they sought, unsuccessfully, to have put before Parliament. The Reverend Frederick Watson carried on a similar campaign through his own lay Protestant organisation. ${ }^{110}$ However, the chances of an effective concerted campaign against "Ne Temere" were scuppered by the wrecking tactics of Ratcliffe who felt aggrieved because he was not acknowledged as the premier Protestant champion on this - and any other - issue. ${ }^{111}$

The Orange Order and other manifestations of militant Protestantism in Scotland did not, therefore, lack ammunition for some of their allegations. There was considerable evidence of Catholic sectarian activity, ${ }^{12}$ and Catholic exclusiveness and Catholic dogmatism. Catholics were patently well organised politically and there were political appeals made, by the Labour Party and Catholic leaders, to Catholics as Catholics. ${ }^{113}$ There were also legislative developments in this period, such as the Catholic Relief Act of 1926, which allowed the Orange Order and others to argue that the state was strengthening the Catholic Church's position while that church was attempting, in relation to matters such as mixed marriages, to undermine the authority of the laws of the state. The 1918 Education Act could also fairly be represented as providing for Catholic teaching in Catholic schools

${ }^{108}$ See Gallagher, Glasgow: The Uneasy Peace, p. 121, and for Orange reaction to a speech by Phillimore (Catholic convert) see $B W N, 27$ November 1930.

${ }^{10}$ Gallagher, Glasgow: The Uneasy Peace, p. 121.

110 See $B W N, 9$ November 1933,16 November 1933 and 18 January 1934. "Ne Temere" provoked the formation of a "National Vigilance Society" on the part of Church of Scotland members.

${ }^{111}$ See Ratcliffe's comments on Watson in Vanguard, 7 February 1934.

112 Labour too could be the victim of it. See Forward, 10 June 1933 regarding the Catholic candidate in the Gorbals division of Glasgow playing the sectarian card against the ILP.

${ }^{113}$ See Knox, "Religion and the Scottish labour movement". Also Vanguard, editorial 6 September 1933. 
while preventing Protestant bible teaching in state schools. The Orange Order's Education Board members in the early 1920s all considered themselves to be fighting, primarily, for the rights of Protestants to receive Protestant religious teaching. ${ }^{114}$ The Order promoted vigorously a view of bible Protestantism, fundamentalist and evangelical in character, although it should not be forgotten that the Order was made up of all Protestant denominations and contained members whose views on what Protestantism meant probably differed on certain points.

Finally, it should also be remembered that the fears and objections expressed by the Order about Catholic activities sometimes found an echo in the mainstream Protestant churches. In 1935 at the Church of Scotland General Assembly Catholic activity was the subject of debate with particular points being made about its purchase of buildings and land, and about the continuation of immigration from the Irish Free State. The Reverend W.A. Guthrie condemned the 1918 Education Act and claimed that the Catholic church had made astute use of it to improve its position in Scotland. He claimed - and in this he played the same numbers game as Orange leaders - that the Catholic school population had increased $28 \%$ in the previous 20 years as against a Protestant increase of only $5 \%$ in the same period. The Assembly ended up agreeing to consider what steps should be taken to secure an amendment of the 1918 Act. ${ }^{115}$

The point to emphasise here is once again the way Catholic activity was perceived. Objectively, the Orange Order's influence on Scottish society, not to mention its numerical strength, was far greater than that of the $\mathrm{AOH}$ or the Knights of St. Columba. Moreover, displays of Catholic devotion at Carfin and elsewhere hardly qualify for the label "sectarian". However, Orange Order members and many ordinary Protestants never felt obliged to distinguish between different types of Catholic activity or to assess the significance of Catholic organisations; they were simply encouraged, sometimes even by so-called "respectable" figures, to view all such activity as a threat.

\section{The nature of the Order's Scottishness}

The Orange Order was both a religious and political organisation; its religious concerns helped shape its politics. It saw the defence of Britain's Protestant monarchy and constitution as paramount. It viewed the Empire in the context of a wider Protestant civilisation which guaranteed rights and liberties: "freedom, religion and laws" as one of its slogans ran. This stress

114 See reflections of Reverend Victor Logan on education, $B W N, 20$ March 1930.

${ }^{115}$ Reported in $B W N, 6$ June 1935. See also Callum Brown The Social History of Religion, pp. 201-202. 
on Empire was, somewhat ironically, offered as proof of the Order's breadth of vision. Grand Master McInnes Shaw, who was most prone to imperialistic sentiment, was eulogised at an Orange gathering in his honour in 1931 as follows: "He (McInnes Shaw] was an Orangeman of the Empire, an Orangeman of Imperial vision and with splendid ideals, an Orangeman in whose broad British mind the petty sentiments of the Little Englander never found a place." 116

Celebration of all things British logically led to rejection of Scottish Nationalism. This was also the product of a belief, on the part of the leadership at least, that Scottish Nationalism, was Catholic-influenced. McInnes Shaw stated in 1930: "The moving spirit behind the National party in Scotland, those who wanted to see Scotland separated from England, were Roman Catholics." 117 Two years later, after claiming that no-one was more proud of being Scottish (he frequently appeared in public in highland dress), he claimed that a separate Scotland would be in the Catholic Church's interests and that some of those preaching nationalism were not "true blues". 118

However, the Orange Order was careful to play on Scottish Nationalist sentiment of a particular kind, namely the history and legacy of the Covenanters. In this way both Scottish and Irish Protestant struggles were celebrated as the one cause. As Digby S. Brown put it in a speech in 1929: "The faith they stood for was the faith that was held by the martyred saints, the faith that was held by Scotsmen, ancestors of their own, who died at Drumclog and Bothwell Brig, and the faith held in the sister isle by the men who fought at Derry, Aughrim, Enniskillen and the Boyne."119 Orange leaders, in their tributes to the Covenanters, carefully avoided consideration of the extent to which they stood for a Scottish Nationalist cause as well as Protestant principles. There was, indeed, a simple equation made between Scottish patriotism and the upholding of Protestantism, which for Orangemen and women meant fidelity to the Union. The Order stood for a celebration of Scottishness which revolved around the Covenanters, Robert Burns and David Livingstone. Lodges were named after the latter two as well as famous Covenanters. Burns' Suppers were highlights of the Orange calendar and no social gathering was complete without the rendition of a selection of Burns' songs and ballads. Even some of Burns's more radical and egalitarian sentiments were quoted favourably; a speaker at an Orange Burns' Supper in 1932 took as his text "A Man's a Man for a' That" and

116 BWN, 26 February 1931.

117 Ibid., 26 June 1931.

118 Ibid., 13 October 1932. See also the comments of Sir Robert Horne, Unionist MP for Glasgow Hillhead, as quoted in Mitchell, Conservatives and the Union, p. 41.

${ }^{119} B W N, 10$ January 1929. 
stressed that Burns cared nothing for rank or aristocratic privilege ${ }^{120}$ Here was another irony: egalitarian sentiments being expressed in an organisation noted for its deference towards the wealthy and the propertied. It is another indication that democratic and politically radical instincts could be held by members of the Order and somehow made to fit in with their overall conception of the organisation.

\section{The social dimension}

The subject of Burns' Suppers and sing-songs at Orange gatherings underlines the remarkable social role which the Order also played. Indeed it might be argued that this function was at least on the same level of importance as politics and religion, whatever the views of the leadership on the raison d'être of the movement. The gatherings at which the leaders delivered their political or religious homilies were primarily social events and it was for this reason that they were, in many cases, attended by hundreds of members (and presumably their families and friends). Along with the comforting sense of solidarity and belonging at such gatherings went much entertainment in the form of singing, dancing and poetry recitals. There was a very active Orange choir, and picnics and outings were regular occurrences. Some may have joined for the friendly society type of benefits the Order offered, although, as has been argued, it could not compete with the Labour and cooperative movements in this respect.

Another phenomenon to emphasise is the extent of the involvement in the Order of women. Women's lodges, in fact, were first formed in Scotland in 1909 when the male officials could withstand no longer the pressure being exerted by women to play a properly recognised role. Soon Juvenile lodges were also set up. ${ }^{121}$ Both, especially the women's lodges, proved remarkably successful. By 1934 there were 191 women's lodges. ${ }^{122}$ The Order's General Secretary Joseph Cloughley wrote in 1929: "But for the women's lodges and their large membership, the Orange Order in Scotland would not occupy the proud and powerful position that it does today." 123 A more recent Orange historian has attributed the women's zeal for Orange membership in the early twentieth century to the experience some of them gained through the Conservative Primrose League in that period. ${ }^{124} \mathrm{Cer}$ tainly, it is the case that the women soon proved themselves expert organisers, indefatigable workers for charity, in particular local hospitals, ${ }^{125}$

120 Ibid., 21 January 1932.

121 See article by Joseph Cloughley, $B W N, 5$ December 1929.

122 Ibid., 18 October 1934.

${ }^{123}$ Ibid., 5 December 1929.

124 Rev. G.A. McCracken B.D., Bygone Days of Yore (Glasgow, 1990), p. 38.

${ }^{125}$ See, for example, report in $B W N, 2$ January 1936. 
and, perhaps, more enthusiastically Conservative in a political sense if the motion at the Ladies Orange function referred to earlier is any guide. The Womens' meetings were regularly addressed by leadership figures who made appropriately appreciative noises. For some males the Order's social appeal undoubtedly embraced less savoury activities. The Order clearly functioned as an outlet for young male aggression for, in connection with Orange marches and public meetings, plenty of fights and excitement were guaranteed. This was, in Glasgow at any rate, a period of lurid gang violence, and perhaps the most notorious street gang was the fabled "Billy Boys" of Bridgeton who were involved in some spectacular "Chicagoesque" scenes, particularly in the 1930s. The "Billy Boys" attached themselves to the Orange movement and used its processions as an excuse for a fight; equally, there were plenty of Catholic gangs ready to supply the opposition, and attacks by Catholics on Orange parades were a regular feature of the Glasgow summer in the inter-war years. Lanarkshire was also a cockpit of sectarian violence; the affrays in and around Carfin have been noted. One report of a Bridgeton street battle in which "bayonets were flourished" will convey the flavour of these set-tos: "The arrival of a flute band in Muslin Street is supposed to have precipitated the crisis. Party tunes, it is stated, were being played, when suddenly a section of the crowd began to throw bottles and stones. Fighting ensued, and the whole district was in a ferment." ${ }^{26}$ Public disorder was especially fierce in Glasgow after the Orange Walk in 1935, and the fall out from it might well have affected the grim events in Belfast a week later when the "Billy Boys", over in strength for "the Twelfth", were said to have led Protestant attacks on Catholic districts after the death of a young Protestant in an outburst of sectarian feuding. ${ }^{127}$

Street fighting in connection with political causes and issues was another hallmark of this period, and it clearly bred legends and reputations which, indeed, survive to this day. As such, it had an allure for some young males who saw it as a way of "proving" themselves. However, in the Orange context, the regularity of battle, the extent to which they had to defend themselves from the attacks of outraged Catholics, could be said to have intensified their loyalties and, also, a defensive state of mind which was fed on notions of being under threat. Orangemen took on board the attitude that they would have to "suffer in the cause". Their defensive mentality was in defiance also of most of middle-class Protestant Scottish society which, mainly in the press and the courts, damned them as the worst troublemakers instead of, as the Orangemen thought of the matter, being grateful to them for standing up for Protestantism and loyalty to the Crown and

127 See Hepburn, "The Belfast Riots of 1935". 
constitution. Fighting in the streets, it thus might be said, reinforced not only anti-Catholic prejudices, but also a keen sense of class bitterness.

Orangeism as a defiant kind of working-class identity spread across the popular culture of the period. It pervaded recreational activities, in particular the Scottish working-class male's passion: football. ${ }^{128}$ At the top level of this sport the Old Firm rivalry between Rangers and Celtic institutionalised and glamourized the Orange and Green rivalry, and their matches became great tribal occasions. ${ }^{129}$ Some Rangers players were Orange Order members in this period, ${ }^{130}$ and others who were not were happy to be guests of honour at Orange gatherings. ${ }^{131}$ The Old Firm, however, was only the most obvious and famous religious football rivalry; Orange and Green reputations were also discernible in clubs at lower levels of the game, particularly the "Junior" leagues which were, and are, a sub-culture all of their own in Scotland. ${ }^{132}$ Protestant church organisations like the Boys Brigade, which had a large working-class membership, were noted for their sporting activities, while Catholic youth guilds and clubs spawned numerous football and other sporting teams. Schools football, moreover, could not hope to escape being sectarian-tinged owning to the religious educational division. This whole popular cultural and recreational area would seem ripe for further research into manifestations of sectarian rivalry, and such study would probably shed light on the extent to which there were clearly defined religiously-based neighbourhoods in towns and cities. ${ }^{133}$

\section{Conclusion}

In conclusion it can be said that the Orange Order's influence on lowland Scottish Protestant working-class life between the wars was out of proportion to its numbers. These numbers were impressively large - no other

${ }^{128}$ See H.F. Moorhouse, "Shooting Stars: footballers and working class culture in twentieth century Scotland", in R.J. Holt (ed.), Sport and the Working Class in Modern Britain (Manchester, 1990), pp. 179-197.

${ }^{129}$ See Murray, The Old Firm, passim; also G. Walker, "The Old Firm", History Today, 38 (October 1988), pp. 11-12.

${ }^{130}$ See $O . S$., March 1927. Several Rangers players were said by Connor to be members of Lodge No. 262, "Knox's Purple Guards".

131 See, for example, report of speech at Orange social by Rangers player Dougie Gray, $B W N, 19$ February 1931 .

${ }^{132}$ The "Junior" game was semi-professional. The teams in some localities reproduced the Old Firm rivalry, for example Benburb and St. Anthony's in the Govan area, and Blantyre Victoria and Blantyre Celtic in Blantyre in Lanarkshire.

${ }_{133}$ We can, however, be confident from literary evidence about the Orange and Green character of areas of Glasgow like Partick, Bridgeton and the Gorbals, and towns like Larkhall and Coatbridge, although research into them may reveal complex patterns of residential differentiation. 
single organisation including any in the labour movement was able to put so many people on the street for a demonstration - but, even so, the numbers still only amounted to a small proportion of the Protestant working class. The point, however, was that many people came into contact with it; there were those who joined and then lapsed; there were those who knew people in it, who had family or friends who were members; and there were many who were aware of it culturally because of other associations or activities, professional football-spectating, for example. Arguably it was widely seen, in a period in which sectarian organisations proliferated and a vibrant sub-culture of beliefs and assumptions grew up around them, as a necessary voice for Protestant interests.

However, it also seems to have been the case that most of those outside it who saw it in this light felt they could ignore its political stances, and the same probably applied to significant numbers inside it judging by the evidence on political behaviour which has been presented. The Orange Order was better at getting people out on the streets to celebrate the Battle of the Boyne or to protest about something like the Carfin Grotto than in delivering working-class votes to the Unionists. Moreover, some of the major issues, such as education and mixed marriages, that the Order and other militant Protestant groups were able to exploit successfully, did not break down into convenient and clear political terms.

It is possible to perceive a continuous dialogue over this period, between the values leaders and officials were trying to impose, and the autonomous ones of the rank and file. On different occasions either might be viewed as prevailing. On an occasion like the "Twelfth" celebration both might be said to have prevailed: the apparent enthusiastic display of "King and Country" loyalism and cheers for Conservative leaders, but at the same time, an independent show of working-class culture - raucous, often disorderly and sometimes violent, and always out of middle class "control", as personified, in Orange circles, by certain Church ministers and Unionist politicians, and a few employers. McInnes Shaw might have been cheered for anti-Catholic speeches but, in general, he did not preside over a socially, culturally or politically quiescent or pliable movement.

The Orange Order was part of a culture in which loyalties were accorded to different causes at different times, in which tribal emotion and class consciousness both conflicted with, and at times reinforced, each other. The Order was also indubitably a force which stood for a strong sense of Ulster-Scottish identity and, as such, it should be recognised, along with its Catholic counterparts, as having generated a profound Irish cultural influence in lowland Scotland well into the twentieth century. 